\title{
History, landscape, and botanical report of a centenary square in Brazil
}

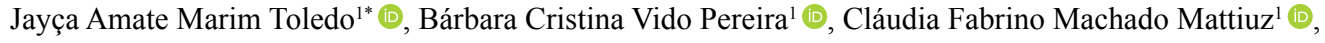 \\ Marcelo Nalin Ambrosano ${ }^{1}$ (D), María Carolina Cásares ${ }^{2}$ (D), Angelo Gabriel Trevisoli Silva ${ }^{1}$ (D), Marcos Vieira Ferraz ${ }^{3}$ (D) \\ ${ }^{1}$ Universidade de São Paulo, Escola de Agricultura “Luiz de Queiroz”, Departamento de Agricultura, Piracicaba, Brazil. \\ ${ }^{2}$ Universidad Centroccidental Lisandro Alvarado, Barquisimeto, Venezuela. \\ ${ }^{3}$ Universidade Estadual Paulista - UNESP, Botucatu, Brazil.
}

\begin{abstract}
Historical research of public spaces provides a better understanding of the social formation and preserve cultural and landscaping heritage. José Bonifácio Square, located in Picacicaba, São Paulo State, Brazil, is an important public space. We carried out a historical survey in the archives of municipal public institutions and a landscape record was done by identifying tree species implanted in the square. We verified a strong church influence in the development of the square landscape project. The first landscaping work occurred in 1885, and it became known as City Public Garden. It presented naturalistic features, using exotic and native species, mainly trees, for landscaping composition. Several modifications and reforms were made from 1885 to 2005. José Bonifácio Square was considered highly diverse $\left(H^{\prime}=3.18\right)$ with 151 individuals, distributed in 36 species belonging to 14 botanical families. The native species from Atlantic Forest represented $82.6 \%$ of Bignoniaceae, Arecaceae, and Fabaceae species. The high diversity of native species found in José Bonifácio Square allowed us to infer a lower ecological fragility and a higher environmental balance than other Brazilian squares. The analysis of historical information from the years 1885 to 2019 and the analysis of the square's floristic composition in contemporary times demonstrated José Bonifácio Square's relevance in forming and conserving Piracicaba's urban identity.
\end{abstract}

Keywords: historical garden, José Bonifácio Square, native trees, urban landscaping.

\section{Resumo}

História, paisagismo e levantamento botânico de uma praça centenária no Brasil

As pesquisas em espaços públicos históricos ajudam a entender a formação das sociedades e a preservar o patrimônio cultural e paisagístico. A Praça José Bonifácio, localizada em Piracicaba, no estado de São Paulo, é um espaço público importante na história da cidade. Um levantamento histórico foi realizado nos arquivos das instituições públicas do município e o registro da paisagem foi feito através da identificação das espécies arbóreas implantadas na Praça. Foi verificada uma forte influência da igreja no desenvolvimento do projeto da Praça estudada. O primeiro projeto paisagístico foi implementado em 1885 e o espaço ficou conhecido como Jardim Público da Cidade, com cenários naturalistas com árvores exóticas e nativas. Foram realizadas muitas reformas e modificações na praça, no período de 1885-2005. Em relação à vegetação, a Praça José Bonifácio foi considerada altamente diversa $\left(\mathrm{H}^{\prime}=3,18\right)$ com 151 indivíduos identificados, distribuídos em 36 espécies pertencentes a 14 famílias botânicas. As espécies botânicas nativas apresentaram frequência de 82,6\%, predominantemente da Mata Atlântica, sendo maior a frequência de espécies de Bignoniaceae, Arecaceae e Fabaceae, que também são frequentemente encontradas em outras praças brasileiras. A alta diversidade florística de espécies nativas encontradas na praça José Bonifácio infere a um equilíbrio ambiental quando comparada a outras praças brasileiras. A análise de informações históricas dos anos de 1885 a 2019, e a análise da composição florística da praça na contemporaneidade demonstrou a relevância da Praça José Bonifácio na formação e conservação da identidade urbana de Piracicaba.

Palavras-chave: jardim histórico, Praça José Bonifácio, árvores nativas, paisagismo urbano.

\footnotetext{
*Corresponding author: jamtoledo@usp.br
} 


\section{Introduction}

Throughout the history of public squares, Greeks, Romans, pre-Hispanics, or modern civilizations created and recreated public spaces far beyond the original purpose for which those spaces were structured. In Greek culture, the first signs of a public square are characterized by three main functions: religious, political, and economical. Historically, the Plaza Mayor is a space that permeates society construction; therefore, it is a place for encounter, connection, integration, and identity (Campos-Cortés, 2011).

Due to Brazilian historical and cultural aspects resulting from the predominantly Catholic colonization, it is common to associate a city center with the main square and a church. Squares' history is directly linked to landscaping historical evolution and customs of a period in which they were created and/or modified. Historic squares were primarily known as public gardens. However, it corresponded to the current public spaces known as squares. The historic gardens contribute to the peoples' memory and identity, and are considered cultural heritage and living monuments. Therefore, the importance of its preservation (Juste and Paiva, 2015).

Similarly, the cultural heritage is relevant for the population's history and culture as the environmental importance of ecological preservation reflects in the population's well-being. The public squares are considered an important green urban space, thus collaborating with urban centers microclimate. Different types of urban green infrastructures participate in a variety of ecological functions as the natural forest. They are indicators of an urban ecological system that contribute to improve the urban ecosystem and benefit the life quality of city residents (Shanahan et al., 2015; Larson et al., 2016; Xie, 2018).

Historical contextualization is relevant for portraying aspects related to transformations over time in public spaces as historical squares. It also reveals the squares' quality to users, evaluates environmental and aesthetic qualities, and provides data to assist plans' guidelines for adapting or revitalizing the place. The revitalization concept is closely linked to the past's valorization, seeking to rescue traditional and collective memory without inhibiting modernity. It includes abandoned areas rehabilitation and historical heritage restoration.

Public squares describe the city and its inhabitants. They are reflections of the society where they are inserted and allow experiencing its urban characteristics. In return, the city and its identity nourish the squares, which are significant places that show and aid in understanding the urban identity (Erdoğan and Ayataç, 2015). Therefore, understanding the origins and the changing of historical urban spaces is essential for urban management and heritage protection. In this context, recent research studies have contributed to the history and landscaping design of significant Brazilian squares (Alves et al., 2015; Mundin et al., 2017; Luz and Paiva, 2020).

José Bonifácio Square is considered an important urban reference of Piracicaba since 1885. It is the municipality's main square since it hosts the main church and is the first public square in the city's history. The square is currently located in an important commercial area of the municipality. Despite its importance, it was found a few historical and landscape records about José Bonifácio Square. Thus, we aimed to carry out a historical-landscape inventory and a landscape survey of José Bonifácio Square's botanical diversity.

\section{Material and Methods}

José Bonifácio Square has an area of $17,888 \mathrm{~m}^{2}$ approximately and is located in Piracicaba, São Paulo, Brazil. The square landscape historical data were collected by documental, iconographic, and bibliographic research. The review was accomplished at the Institute of Research and Planning, the City Council of Piracicaba, the Historical and Geographical Institute of Piracicaba, and on official websites of Piracicaba city's history. The historical images were provided by the Institute of Mnemosine of Piracicaba and by the Historical and Geographical Institute of Piracicaba.

A vegetation inventory was carried out in 2016 . The quantification of individuals per species included the large palms trees, referred to as "trees" in our study to facilitate the data presentation. The identification of the species in the field was carried out with literature (Lorenzi, 2016).

The analysis consisted of plant identification in species and botanical families, species richness quantification, individual relative frequency, relative species abundance, and Shannon-Wiener diversity index $\left(\mathrm{H}^{\prime}\right)$ of species identified in the square (Shannon and Wiener, 1949). We used the Angiosperm Phylogeny Group IV classification system based on the phylogenetic approach (Byng et al., 2016).

Identified species were classified as Brazil's native or exotic. We included the origin place for exotic species and the Brazilian biomes for native species. Statistical analysis and graphs were generated using Past 3.23 software (Hammer et al., 2001).

\section{Results}

Historical and architectural origins, social and cultural importance

José Bonifácio Square has developed as a huge relevancy space due to a long historical process resulting in a cultural landmark. Piracicaba was officially founded on August ${ }^{\text {st }}, 1767$, on the Piracicaba River's right bank (Torres, 2009), firstly called "Freguesia Santo Antonio de Piracicaba". However, the demarcation of the place that nowadays is called José Bonifácio Square occurred in 1784 after a necessity of a new delimitation of the village on the left bank of the Piracicaba river (Guerrini, 2009; IBGE, 2020).

The Catholic church's relevancy ahead the urban development results from a medieval reference since the church was an essential building for society's culture and faith, mainly from the $11^{\text {th }}$ century (Campos-Cortés, 2011). 
Similarly, in the Brazilian colonial period, villages〉 urban morphology was based on chapels and public spaces. These important urban landmarks were responsible for maintaining the bond between the community and the clergy, which was tightly respected by the Portuguese monarchy. Thus, José Bonifácio Squaress church has attracted many surrounding residential constructions and public and trade buildings (Robba and Macedo, 2003).

In most Brazilian cities, the occupied and constructed area by the Catholic church was the commercial and residential center of the villages. The first mention of a new church in José Bonifácio Square dates to 1822 . However, only in 1824, its construction was delimited, and the planning began. Officially, the construction started in 1832 .
The oldest church was simple, made of mud, and presented a wooden tower. A newest church was built around the oldest one, designed by Miguel Dutra in a baroque style. It was completed between 1870 and 1875. (Cachioni, 2012).

The first mentions of the landscaping at the cathedral's square dates to 1883 . However, the landscaping was only built in 1885, and it became known as the City's Public Garden (Figure 1).

The garden had attractive animal and bird species and iron benches for public use (Guerrini, 2009). Guerrini (2010) reported that a pavilion was inaugurated at the cathedral's square in 1892. There was a large fountain, surrounded by grass and iron arabesques. Nearby, there was a large tree woodland providing abundant shade (Figure 2).

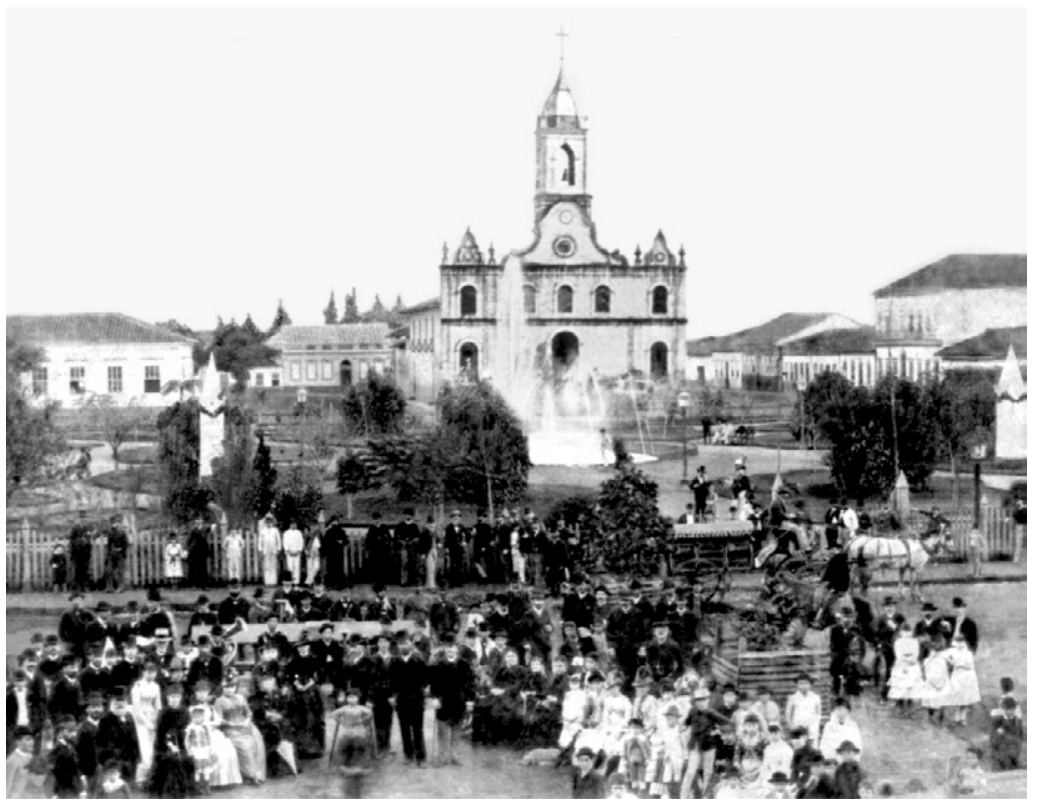

Figure 1. City's public garden: Cathedral square public garden in 1887 during a city's political party. Source: Municipal chamber of Piracicaba files.



Figure 2. Large trees in José Bonifácio Square in Piracicaba city, 1892. Source: Institute of Mnemosyne. 
A bandstand represented, even nowadays, an important type of building in Brazilian squares. In 1892, José Bonifácio Square was inaugurated along with its bandstand, which represented a stage for musical concerts and political discourses. In August 1893, the Santo Antônio Cathedral, the Santo Estevão theater, the Public Garden, and some streets received public lighting. Three years later, an electricity company installed lights in the square fountain and inaugurated it (Torres, 2009; Guerrini, 2010). From 1917 to 1925, the government's administration refurbished the garden of José Bonifácio Square. The garden's refurbishment portrayed a French-style design. Furthermore, some neoclassical elements brought to the Cathedral provided a European architecture design of the $20^{\text {th }}$ century (Cachioni, 2012).

In 1939, a fire destroyed the whole internal part of the Santo Antônio Cathedral. The reconstruction project for the burned cathedral begun in 1946 (IBGE, 2020). Architect Benedito Calixto de Jesus Neto carried out the architectural project in a romantic style and the project execution by engineer Antonio Habechian. The construction was completed in 1961. However, it was officially inaugurated in 1958 (Cachioni, 2012).

Many monuments were inaugurated in the square. Among them, the Soldado Constitucionalista' monument was installed in 1938 to honor the combatants of the Revolution of 1932. Other monuments were installed at the José Bonifácio Square to honor local and national personalities, such as the important municipality's writer and professor Herma Sud Mennucci, in 1892, and removed from the square in 1981 . The monument of the greatest revolutionary of the $19^{\text {th }}$ century, called Luiz de Queiroz, was installed in 1959, and the Mario Dedini monument was inaugurated in 1961 in honor of the brilliant industrialist (Pfromm Netto, 2015).

In 1980, the "Action plan for Piracicaba's downtown renovation" was implemented. In this renovation, José Bonifácio Square had priority intervention, and the two streets were added to the square area as pedestrians pathway, blocking vehicles access around the square. According to Guerrini (2010), José Bonifácio Square incorporated three public spaces: the Santo Antonio Cathedral, a large area in front of the cathedral, and the September $7^{\text {th }}$ Square in 1945.

Throughout the years, José Bonifácio Square has been one of the busiest urban spaces of Piracicaba city, hosting events sponsored by the Municipal Secretary of Tourism (Setur). Saint Anthony's celebration is the most traditional festivity for the city's patron each June $13^{\text {th }}$.

The José Bonifácio Square underwent a revitalization in 2019 with smaller repair and other larger modifications which changed its characteristics. The fountain was removed, and the place where it was located was repaved, as approved by the Piracicaba's Cultural Heritage Defense Council. Also, tactile paving was introduced for visually impaired people, including a regular playground replacement by a visually accessible playground. Several flowerbeds were recovered, bushes and grasses were replanted (Destro, 2019).

Nowadays, the square has a large diversity of trees containing 151 individuals distributed in 36 species and 14 families (Table 1). 



Individuals number; RF: relative frequency; Values of Shannon-Wiener diversity index (H'). * Endemic of Atlantic Forest.

\begin{tabular}{|c|c|c|c|c|c|c|c|c|c|c|c|c|c|}
\hline \multirow[b]{2}{*}{ FAMILY /SPECIE } & \multirow[b]{2}{*}{ COMMON NAME } & \multirow[b]{2}{*}{ ORIGIN } & \multicolumn{6}{|c|}{ DISTRIBUTION IN BRAZIL } & \multirow[b]{2}{*}{ IN } & \multirow[b]{2}{*}{$\mathbf{R F}$} & \multicolumn{3}{|c|}{$\mathbf{H}^{\prime}$} \\
\hline & & & Amazonia & $\begin{array}{l}\text { Atlantic } \\
\text { Forest }\end{array}$ & Caatinga & Cerrado & Pampa & Pantanal & & & pi & $\log N / p i$ & pi $x \operatorname{LogN} / p i$ \\
\hline Apocynaceae & & & & & & & & & 2 & 1.32 & & & \\
\hline Aspidosperma parvifolium & Guatambú & Brazilian & A & $\mathrm{P}^{*}$ & A & A & A & A & 1 & 0.66 & 0.01 & -5.02 & -0.03 \\
\hline Aspidosperma polyneuron & Peroba-Rosa & Brazilian & A & $\mathrm{P}$ & A & A & A & A & 1 & 0.66 & 0.01 & -5.02 & -0.03 \\
\hline Araliaceae & & & & & & & & & 11 & 7.28 & & & \\
\hline Schefflera actinophylla & Cheflera & Oceania & - & - & - & - & - & - & 10 & 6.62 & 0.07 & -2.71 & -0.18 \\
\hline Tupidanthus calyptratus & Tupidanto & Asia & - & - & - & - & - & - & 1 & 0.66 & 0.01 & -5.02 & -0.03 \\
\hline Arecaceae & & & & & & & & & 32 & 21.19 & & & \\
\hline Dypsis madagascariensis & Areca-de-Locuba & Africa & - & - & - & - & - & - & 6 & 3.97 & 0.04 & -3.23 & -0.13 \\
\hline Euterpe edulis & Palmito-Jussara & Brazilian & A & $\mathrm{P}$ & A & $\mathrm{P}$ & A & A & 7 & 4.64 & 0.05 & -3.07 & -0.14 \\
\hline Livistona chinensis & $\begin{array}{l}\text { Palmeira Leque-da- } \\
\text { China }\end{array}$ & Asia & - & - & - & - & - & - & 4 & 2.65 & 0.03 & -3.63 & -0.10 \\
\hline Ptychosperma macarthurii & $\begin{array}{l}\text { Palmeira-de } \\
\text { Macarthur }\end{array}$ & Oceania & A & $P$ & A & A & A & A & 14 & 9.27 & 0.09 & -2.38 & -0.22 \\
\hline Roystonea oleracea & Palmeira-Imperial & $\begin{array}{l}\text { South } \\
\text { America }\end{array}$ & A & $P$ & A & A & A & A & 1 & 0.66 & 0.01 & -5.02 & -0.03 \\
\hline Bignoniaceae & & & & & & & & & 34 & 22.52 & & & \\
\hline $\begin{array}{l}\text { Handroanthus } \\
\text { chrysotrichus }\end{array}$ & Ipê-Amarelo & Brazilian & A & $\mathrm{P}$ & A & $P$ & A & A & 5 & 3.31 & 0.03 & -3.41 & -0.11 \\
\hline Handroanthus heptaphyllus & Ipê-Rosa & Brazilian & A & $\mathrm{P}$ & A & $\mathrm{P}$ & A & A & 12 & 7.95 & 0.08 & -2.53 & -0.2 \\
\hline $\begin{array}{l}\text { Handroanthus } \\
\text { impetiginosus }\end{array}$ & Ipê-Roxo & Brazilian & A & $P$ & $\mathrm{P}$ & $P$ & A & $\mathrm{P}$ & 12 & 7.95 & 0.08 & -2.53 & -0.2 \\
\hline Handroanthus umbellatus & $\begin{array}{l}\text { Ipê-Amarelo-do- } \\
\text { Brejo }\end{array}$ & Brazilian & A & $\mathrm{P}$ & $\mathrm{P}$ & $P$ & A & A & 3 & 1.99 & 0.02 & -3.92 & -0.08 \\
\hline Tabebuia roseoalba & Ipê-Branco & Brazilian & A & $\mathrm{P}$ & $\mathrm{P}$ & $\mathrm{P}$ & A & A & 2 & 1.32 & 0.01 & -4.32 & -0.06 \\
\hline Chrysobalanaceae & & & & & & & & & 1 & 0.66 & & & \\
\hline Licania tomentosa & Oiti & Brazilian & A & $\mathrm{P}^{*}$ & A & A & A & A & 1 & 0.66 & 0.01 & -5.02 & -0.03 \\
\hline Euphorbiaceae & & & & & & & & & 1 & 0.66 & & & \\
\hline Hevea brasiliensis & Seringueira & Brazilian & $\mathrm{P}$ & A & A & A & A & A & 1 & 0.66 & 0.01 & -5.02 & -0.03 \\
\hline
\end{tabular}


Table 1. cont

\begin{tabular}{|c|c|c|c|c|c|c|c|c|c|c|c|c|c|}
\hline Fabaceae & & & & & & & & & 25 & 16.56 & & & \\
\hline Cenostigma pluviosum, & Sibipiruna & Brazilian & $\mathrm{P}$ & $\mathrm{P}$ & $\mathrm{P}$ & $\mathrm{P}$ & A & $\mathrm{P}$ & 8 & 5.3 & 0.05 & -2.94 & -0.16 \\
\hline Erythrina mulungu & Mulungu & Brazilian & A & A & A & $\mathrm{P}$ & A & $\mathrm{A}$ & 1 & 0.66 & 0.01 & -5.02 & -0.03 \\
\hline Holocalyx balansae & $\begin{array}{l}\text { Alecrim-de- } \\
\text { Campinas }\end{array}$ & Brazilian & A & $\mathrm{P}$ & $\mathrm{P}$ & $\mathrm{P}$ & A & A & 1 & 0.66 & 0.01 & -5.02 & -0.03 \\
\hline Hymenaea courbaril & Jatobá & Brazilian & $\mathrm{P}$ & $\mathrm{P}$ & $\mathrm{P}$ & $\mathrm{P}$ & A & $\mathrm{P}$ & 1 & 0.66 & 0.01 & -5.02 & -0.03 \\
\hline Libdibia ferrea & Pau-Ferro & Brazilian & A & $\mathrm{P}$ & $\mathrm{P}$ & $\mathrm{P}$ & A & $\mathrm{A}$ & 1 & 0.66 & 0.01 & -5.02 & -0.03 \\
\hline Myroxylon peruiferum & Óleo-Balsamo & Brazilian & A & $\mathrm{P}$ & A & $\mathrm{P}$ & A & A & 6 & 3.97 & 0.04 & -3.23 & -0.13 \\
\hline Paubrasilia echinata & Pau-Brasil & Brazilian & A & $\mathrm{P}^{*}$ & A & $\mathrm{A}$ & A & A & 3 & 1.99 & 0.02 & -3.92 & -0.08 \\
\hline Samanea saman & Árvore-da-Chuva & Brazilian & $\mathrm{P}$ & A & $\mathrm{P}$ & A & A & $\mathrm{P}$ & 3 & 1.99 & 0.02 & -3.92 & -0.08 \\
\hline Tipuana tipu & Tipuana & $\begin{array}{c}\text { South } \\
\text { America }\end{array}$ & A & $\mathrm{P}$ & A & $\mathrm{P}$ & $\mathrm{A}$ & A & 1 & 0.66 & 0.01 & -5.02 & -0.03 \\
\hline Lauraceae & & & & & & & & & 5 & 3.31 & & & \\
\hline Nectandra megapotamica & Canelinha & Brazilian & A & $\mathrm{P}$ & A & $\mathrm{P}$ & A & A & 5 & 3.31 & 0.03 & -3.41 & -0.11 \\
\hline Lecythidaceae & & & & & & & & & 8 & 5.3 & & & \\
\hline Cariniana estrellensis & Jequitibá-Rosa & Brazilian & A & $\mathrm{P}$ & A & $\mathrm{P}$ & A & A & 3 & 1.99 & 0.02 & -3.92 & -0.08 \\
\hline Couratari asterotricha & Imbirema & Brazilian & A & $\mathrm{P}^{*}$ & A & A & A & A & 5 & 3.31 & 0.03 & -3.41 & -0.11 \\
\hline Lythraceae & & & & & & & & & 12 & 7.95 & & & \\
\hline Lafoensia glyptocarpa & Mirindiba & Brazilian & A & A & A & $\mathrm{P}$ & A & A & 12 & 7.95 & 0.08 & -2.53 & -0.20 \\
\hline Meliaceae & & & & & & & & & 1 & 0.66 & & & \\
\hline Melia azedarach & Cinamomo & Asia & $\mathrm{P}$ & $\mathrm{P}$ & $\mathrm{P}$ & $\mathrm{P}$ & A & A & 1 & 0.66 & 0.01 & -5.02 & -0.03 \\
\hline Moraceae & & & & & & & & & 14 & 9.27 & & & \\
\hline Artocarpus heterophyllus & Jaca & Asia & $\mathrm{P}$ & $\mathrm{P}$ & $\mathrm{P}$ & A & A & A & 1 & 0.66 & 0.01 & -5.02 & -0.03 \\
\hline Ficus leprieurii & Figueira-triangular & Africa & - & - & - & - & - & - & 12 & 7.95 & 0.08 & -2.53 & -0.20 \\
\hline Morus alba & Amora & Asia & - & - & - & - & - & - & 1 & 0.66 & 0.01 & -5.02 & -0.03 \\
\hline Myrtaceae & & & & & & & & & 3 & 1.99 & & & \\
\hline Callistemon viminalis & Escova-de-Garrafa & Oceania & A & $\mathrm{P}$ & A & A & A & A & 2 & 1.32 & 0.01 & -4.32 & -0.06 \\
\hline Eugenia uniflora & Pitanga & Brazilian & A & $\mathrm{P}$ & A & $\mathrm{P}$ & $\mathrm{P}$ & A & 1 & 0.66 & 0.01 & -5.02 & -0.03 \\
\hline Rutaceae & & & & & & & & & 2 & 1.32 & & & \\
\hline Murraya paniculata & Falsa-Murta & Asia & - & - & - & - & - & - & 2 & 1.32 & 0.01 & -4.32 & -0.06 \\
\hline
\end{tabular}


The higher relative frequency (RF) species were Ptychosperma macarthurii (9.27\%) known as Macarthur palm, Lafoensia glyptocarpa (7.95\%) called Mirindiba-rosa, Handroanthus heptaphyllus (7.95\%) known as Pink Trumpet Tree, Ficus leprieurii (7.95\%) called Figueira-triangular, Handroanthus impetiginosus (7.89\%) known as Ipê-roxo and Cenostigma pluviosum (5.30\%) known as Momoqui.
Shannon-Wiener diversity index (H') was 3.18, indicating a high diversity of species. Bignoniaceae presented the major number with 34 individuals and $22.52 \%$ of frequency, followed by Arecaceae with 32 individuals (21.19\%), and Fabaceae with 25 individuals $(16.55 \%)$ (Figure $3 a)$.
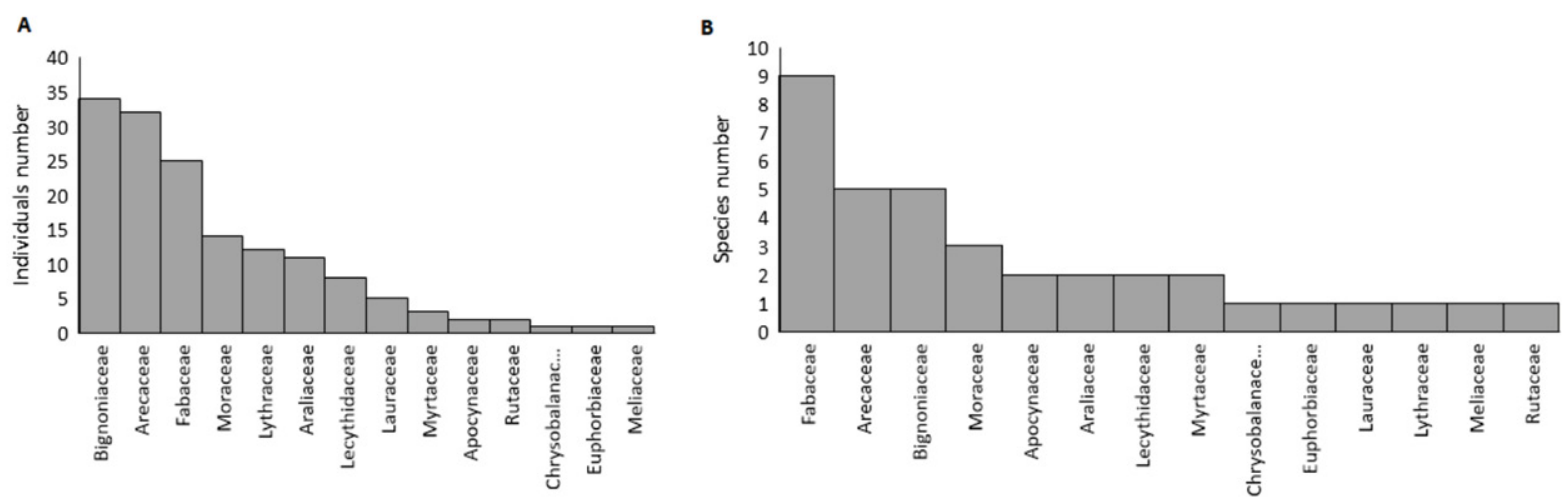

c

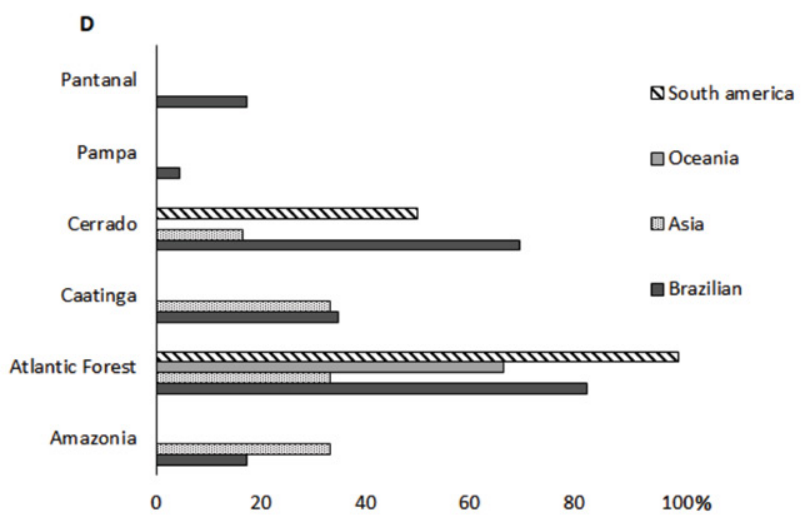

Figure 3. The vertical bar charts represent the sheer number of individuals of trees (a) and species (b) observed for each botanical family at the José Bonifácio Square. c: The graph shows the frequency of trees' origins found at José Bonifácio Square. d) The horizontal bar chart illustrates the proportion of tree species at José Bonifácio square, which might be found in each Brazilian region according to their origins.

The highest diversity of species within families was Fabaceae $\left(\mathrm{H}^{\prime}=1.86\right)$, followed by Bignoniaceae $\left(\mathrm{H}^{\prime}=\right.$ $1.40)$ and Arecaceae $\left(\mathrm{H}^{\prime}=1.38\right)$ (Figure $\left.3 \mathrm{~b}\right)$. The highest species frequency within these families was $P$. macarthurii (9.21), H. heptaphyllus and H. impetiginosus (7.95), and Cenostigma pluviosum (5.30) (Table 1).

The Brazilian native plants' individuals represented $63 \%$ of the arboreal collection, $82.6 \%$ found in the Atlantic Forest (Figures 3c, d). The majority of the identified species are found in more than one Brazilian biome (Table 1; Figure 3d). Species richness of native species belongs to each biome as follows: Atlantic Forest biome (82.6\%), Savanna (Cerrado) (69.56\%), Caatinga (34.78\%), Tropical Rainforest (Amazonia) (17.4\%), Wetland (Pantanal) (17.39\%) and Prairies (Pampas) (4.35\%).

Several plant species are found in the Atlantic Forest are descendants of other continents, such as Artocarpus heterophyllus from Asia, Callistemon viminalis and $P$. macarthurii from Oceania, and Roystonea oleracea from South America except for Brazil. The endemic species of the Atlantic Forest were Aspidosperma parvifolium, Couratari asterotricha, Licania tomentosa, and Paubrasilia echinata, representing $6.62 \%$ of the frequency observed. The arboreous species belonging to Brazilian biomes that do not occur in the Atlantic Forest were $17.4 \%$ of the species: Hevea brasiliensis from Amazonia (0.66\%); Lafoensia glyptocarpa (7.95\%) and Erythrina mulungu $(0.66 \%)$ from Cerrado; and Samanea saman (1.99\%) from Pantanal, Caatinga, and Amazonia. The exotic species were 12 belonging to Asia (6.62\%), Oceania (17.22\%), Africa (11.92\%), and South America (1.32\%). The results showed a prevalent number of exotic species of Asian origin. On the other hand, there was a higher species relative frequency of Oceanian origin. 


\section{Discussion}

\section{Historical-cultural landscaping at José Bonifácio Square, Piracicaba, São Paulo}

José Bonifácio Square is situated in the Atlantic Forest and is considered one of Brazil's most relevant biomes and the most degraded throughout the last centuries. The development of José Bonifacio Square in Piracicaba is intrinsic to Brazilian colonial history. Also, Brazilian squares present European style characteristics such as the construction of Catholic churches. Those are designed on European art concept, as the Baroque style's church inaugurated in 1875 in José Bonifácio Square (Diehl and Vitti, 1989; Cachioni, 2012). Baroque art was already seen since the $18^{\text {th }}$ century in Brazil. It was known as "Brazilian Baroque" and was first recognized in Ouro Preto, São João del Rey, and Sabará in Minas Gerais State. The Brazilian baroque movement differed from the European baroque in some aspects, as the movement occurred in Europe around two centuries before. This fact showed a distinct reason for movement expansion. In Europe, Baroque art was born as counter-reformist, while in Brazil, it was an artistic tradition (Funari and Senatone, 2015). Moreover, the renaissance was introduced under considerable European influence, including the square as the city's central position and high hierarchy buildings (Campos-Cortés, 2011).

Like many Brazilian cities of the colonial period, Piracicaba had a chapel as the settlement's landmark. In the neighborhood of these religious buildings, the first public spaces emerged, as reported at notorious squares of colonial cities such as Congonhas and Ouro Preto (Juste and Paiva, 2015; Alves et al., 2015).

Square space is considered a privileged place for political and popular events (Campos-Cortés, 2011). Thus, several festivities were carried out in colonial squares as the publication of decrees at the church door, the acclamation of Dom Pedro I to Constitutional Emperor, and slavery's abolition. Another common fact was the person's burial inside the church or in the church square, due to the absence of a public cemetery (Guerrini, 2009a; Guerrini, 2010).

According to Robba and Macedo (2003), in 1892, when the Santo Antônio Cathedral was inaugurated in José Bonifácio square, the romanticism movement influenced the garden design. The fantastic, poetic, and reverent style that characterized the romantic period emerged in landscaping toward naturalism and returned to the idyllic landscapes represented by artists of the last centuries.

The urbanization process had started in the later $19^{\text {th }}$ century and occurred throughout the $20^{\text {th }}$ century until nowadays. The contribution to the "urban landscaping" term in Brazilian cities increased due to the urbanization process (Alves et al., 2015). Currently, Brazilian urban space has significantly changed its settings and layout characteristics, even cultural updates. The citizens have acquired landscape habits through streets afforestation and introducing green spaces at squares and parks by local public administration.

From the beginning of the $20^{\text {th }}$ century, several improvements were made in José Bonifácio Square. The current square has not been following the ancient design previously settlement. Therefore, the square's role had to be restructured by urban planners. Furthermore, the poor management neglected aspects associated with José Bonifácio Square as a powerful heritage. The survival of public spaces occurs due to shared memory. Thus, it might indicate that evolving close to citizenship may lead to security and stability, mainly in shocking or overwhelming circumstances. The city's squares provide a fundamental and social purpose, likewise a mirror of the society, demonstrating urban disparities, political manifestations, or cultural expressions. Public spaces, especially squares, provide referential channellers of memory and a community consensus (Capellà, 2014).

The arboreal composition and ecological importance of José Bonifácio Square

The arboreal composition of squares' landscape has been described in several Brazilian regions (Batista et al., 2013; Tischer et al., 2014; Gomes et al., 2016). José Bonifácio Square shows a large diversity of trees implemented on the historic square. Thus, it is relevant for Piracicaba history and urban greening, as for leisure, and contributing to ecological balance. As reported at the November $15^{\text {th }}$ Square in Ribeirão Preto, São Paulo State, the large arboreal diversity aids against pests and diseases (Romani et al., 2012). The recommendation for better ecological balance management consists of not exceeding the same species frequency $(10 \%)$, genus $(20 \%)$, and family (30\%) according to Santamour Júnior (1990) cited by Romani et al. (2012). However, in José Bonifácio Square, Handroanthus sums $21.19 \%$ of the frequency; thus, it has slightly exceeded the recommended value. On the other hand, the largest frequency in species was $P$. marcathurii $(9.27 \%)$, and within families was Bignoniaceae (22.52\%), which not surpassed the recommended values. Accordingly, the studied square has been considered with high arboreal diversity. These results differ from those found in November $15^{\text {th }}$ Square as the author reported $37.3 \%$ of tree individuals belonging to just three species. The author concluded that the square's arboreal composition might be considered an ecological fragility (Romani et al., 2012). Batista et al. (2013) observed a value that reached $15.7 \%$ of the frequency of Caesalpinia peltophoroides specie known as Sibipiruna (Momoqui) at Dom Assis Square in Jaboticabal, São Paulo. Therefore, the author highlighted the importance of urban planning for urban spaces landscaping as a tool for avoiding several diversity-related failures.

One of José Bonifácio Square's significant results is related to the high frequency of individuals and species of Bignoniaceae, Arecaceae, and Fabaceae. A few studies highlighted Bignoniaceae and Arecaceae for their noteworthy richness of species in several Brazilian squares (Romani et al., 2012; Tischer et al., 2014; Gomes et al., 2016). Fabaceae has already been recognized for its high frequency in urban greening across Brazil. Freitas et al. (2015) observed a frequency of 59.3\% of Fabaceae tree species in four squares in Rio de Janeiro, Brazil. The authors concluded that Fabaceae represents outstanding 
importance for urban green space composition. However, this predominance of a single family might negatively affect the pest incidence in the urban landscape.

Shannon-Wiener index of José Bonifácio Square (3.18) (Table 1) was considered higher than that of other squares with similar historical importance where the Shannon-Wiener index was described. Xie (2018) reported a biodiversity index of 2.66 in 34 green urban spaces in Dublin, Ireland. Brazilian squares showed higher biodiversity through the Shannon-Wiener index beyond the José Bonifácio Square and some anthropized spaces such as the University of Acre Campus, in Rio Branco, Brazil $\left(H^{\prime}=3.95\right)$ (Maranho and De Paula, 2014) and Ribeirão Preto's square presenting H'= 3.14 (Romani et al., 2012). In comparison, the values for the Shannon-Wiener index of unperturbed areas of Atlantic Forest ranges from 3.91 to 4.71 (Reis et al., 2015).

At José Bonifácio Square, it is verified a predominance of Brazil native arboreal plants $(63 \%)$. The most frequent species observed are P. macarthurii, L. glyptocarpa, $H$. heptaphyllus, F. leprieurii, H. impetiginosus, C. pluviosum, $P$. MacArthur, and F. leprieurii. The two latter are exotic species from Oceania and Africa, respectively. Similar results were reported in Coqueiros do Sul, Brazil, where Melo et al. (2019) found $60.6 \%$ of Brazilian native species. According to the author, an inappropriate management decreasing the frequency of native species might lead to ecological imbalance and facilitate weed insertion. Moro et al. (2014) in Fortaleza, Brazil and Martins and Correa (2017) in Araras, Brazil, observed 70 and $85.7 \%$ of exotic species, respectively. Only $14 \%$ of the native species of the vegetation were also represented in Fortaleza treescape, and, in general, they included only a few individuals. Cities presenting few native tree species should be re-evaluated to value native plants. It could be used for environmental education and publicize native biodiversity to citizens and might be useful for establishing ecological corridors (Souza et al., 2014).

Exotic trees individuals described in this work are often used in urban greening (Martins and Correa, 2017). They are from Asia, Africa, Oceania, and other South American countries (Table 1; figure 3c). Among them, four species are considered Brazilian naturalized: Artocarpus heterophyllus Lam., Melia azedarach L., Morus alba L. and, Schefflera actinophylla (Endl) Harms (Lorenzi, 2016).

Tree species diversity promotes a variety of colors throughout the year due to different species flowering times. Handroanthus impetiginosus (Mart. ex DC) Mattos blooms from May to August; H. heptaphyllus (Vell.) Mattos and Erythrina mulungu Mart, bloom from July to September; Handroanthus chrysotrichus (Mart ex DC), Mattos and Handroanthus roseo-Albus (Ridl.) Mattos bloom in August, and P. echinata (Lam.) Gagnon, H. C. Lima \& G. P. Lewis bloom from September to October. Five palm species were identified: $43.75 \%$ correspond to Ptychosperma macarthurii (H. Wendl. ex H. J. Veitch)
H. Wendl. ex Hook. f., an exotic species and one native species, Euterpe edulis Mart.

According to Rodrigues' (1999) classification, nine from 14 tree families identified have semi-deciduous seasonal forest characteristics: Apocynaceae, Bignoniaceae, Euphorbiaceae, Lauraceae, Lecythidaceae, Leguminosae, Meliaceae, Myrtaceae, and Rutaceae. They characterize by partial leaves loss in the dry season. The term seasonal accurately expresses behavior or aspect transformations of these species according to seasons.

Azevedo and Gonçalves (2010) affirm that tree vegetation brings numerous benefits, such as air purification, retention of soil and air humidity because of shade, sun protection for users, fauna housing, noise muffling, and contributes to urban attraction, leaving the environment agreeable for residents. Trees aid in pollutant retention, carbon dioxide consumption, oxygen production, and air quality improvement. Also, vegetative barriers can reduce dust spread and block sound propagation, reducing the noise level.

\section{Conclusions}

Historical landscaping survey fulfilled in José Bonifacio Square highlighted its importance to Piracicaba's urban identity and its preservation as cultural heritage. The square's history related portrays a recent composition over time that could be sustained for several modifications throughout the years.

The vegetation composition presented a large diversity from several biomes of Brazil and other continents. Also, Jose Bonifácio Square contains $63 \%$ of trees from Brazilian's native trees, including endemic species from the Atlantic Forest. Therefore José Bonifácio square might be considered huge diverse and representative of your origin region with a high frequency of trees from Atlantic Forest.

\section{Author Contribution}

J.A.M.T.: conceived and designed the analysis, collected the data, contributed data or analysis tools, performed the analysis, wrote the paper. B.C.V.P.: conceived and designed the analysis, collected the data, contributed data or analysis tools, performed the analysis, wrote the paper. C.F.M.M.: conceived and designed the analysis, contributed data or analysis tools, performed the analysis, wrote the paper. M.N.A.: performed the analysis, wrote the paper. M.C.C.: performed the analysis, wrote the paper. A.G.T.S.: performed the analysis, wrote the paper. M.V.F.: wrote the paper.

\section{Acknowledgements}

We thank the Piracicaba Municipal Chamber and Historical and Geographical Institute (IHGP), and Institute of Mnemosine of Piracicaba for the permission to use ancient photographs of José Bonifácio Square. 


\section{References}

ALVES, S.F.N.S.C.; GARCIA, C.S.G.; PAIVA, P.D.O. Physical transformation and social appropriations of the Tiradentes square in Ouro Preto- $M G$, Ornamental Horticulture, v.21, n.2, p.209-220, 2015. https://doi. org/10.14295/aohl.v21i2.670

AZEVEDO, J., GONÇALVES, A. Manual de Boas Práticas em Espaços Verdes. vol 1. Bragança: Câmara Municipal de Bragança, 2010. 177p.

BATISTA, G.S.; BORELLA, H.D.; GIMENES, R.; ROMANI, G.N.; PIVETTA, K.F.L. Análise qualiquantitativa da vegetação e dos elementos arquitetônicos da praça Dom Assis, Jaboticabal, São Paulo Revista Brasileira de Horticultura Ornamental, v.19, n.1, p.7-18, 2013. https://doi.org/10.14295/rbho.v19i1.423

BYNG, J.W.; JUDD, W.S.; SOLTIS, D.E.; MABBERLEY, D.J.; SENNIKOV, A.N.; SOLTIS, P.S.; STEVENS, P.F. An update of the Angiosperm Phylogeny Group classification for the orders and families of flowering plants: $A P G I V$. Botanical Journal of the Linnean Society, v.181, n.1, p.1-20, 2016.

CACHIONI, M. Igrejas. In: CACHIONI, M. Matriz de Santo Antônio. Piracicaba: Instituto Histórico e Geográfico de Piracicaba. Departamento do patrimônio histórico - Instituto de pesquisa e planejamento de Piracicaba, 2012. p.15-17.

CAMPOS-CORTÉS, G.I. El origen de la plaza pública en México: usos y funciones sociales. Argumentos, v.24, n.66, p.83-119, 2011.

CAPELLÀ, H. El retorno a la plaza: un caso de estudio en Concepción (Chile). Cuadernos de geografía: Revista Colombiana de Geografía, v.23, n.1, p.39-45, 2014.

CENSO DEMOGRÁFICO 2010. Características da população e dos domicílios: resultados do universo. Piracicaba: IBGE, 2010. Available at: https://sidra.ibge. gov.br/pesquisa/censo-demografico/demografico-2010/ inicial. Accessed on: Sept 012020.

DESTRO, E. Prefeitura inicia $2^{\text {a }}$ etapa de revitalização da Praça José Bonifácio. Prefeitura do município de Piracicaba, Piracicaba, 09 de setembro de 2019. Available at: < https://bit.ly/2F2fstx> Accessed at: Sept 012020.

DIEHL, J.S.; VITTI, G. Piracicaba: dois estudos. A Igreja Matriz de Piracicaba através dos tempos; Memória descritiva do córrego ltapeva e do Rio Piracicaba. vol.1. Piracicaba: Instituto Histórico e Geográfico de Piracicaba, 1989. $119 \mathrm{p}$.

ERDOĞAN, B.D.; AYATAÇ, H. Assessment of urban identity characteristics in public places: A case study of Ortaköy Square. A|Z ITU Journal of the Faculty of Architecture, v.12, n.1, p.115-125, 2015.
FREITAS, W.K.; PINHEIRO, M.A.S.; ABRAHÃO, L.L.F. Análise da arborização de Quatro Praças no Bairro da Tijuca, RJ, Brasil. Floresta e Ambiente, v.22, n.1, p.23-31, 2015.

FUNARI, P.P.A.; SENATONE, M.X. Archaeology of Culture Contact and Colonialism in Spanish and Portuguese America. vol.1. Switzerland: Springer London, 2015. 365 p.

GOMES, E.M.C.; RODRIGUES, D.M.S.; SANTOS, J.T.; BARBOSA, E.J. Análise quali-quantitativa da arborização de uma praça urbana do Norte do Brasil. Nativa, v.4, n.3, p.179-186, 2016.

GUERRINI, L. Piracicaba em quadrinhos. vol.1. Piracicaba: Editora Equilíbrio, 2009a. 400p.

GUERRINI, L. Piracicaba em quadrinhos. vol.2. Piracicaba: Editora Equilíbrio, 2009b. 324p.

GUERRINI, L. A semana na História. vol.1. Piracicaba: Editora Equilíbrio, 2010. 214 p.

HAMMER, O.; HARPER, D.A.; RYAN, P.D.; PAST: Paleontological Statistics Software Package for Education and Data Analysis. Palaeontology Electronica, v.4, n.1, p.1-9, 2001.

JUSTE, L.C.; PAIVA, P.D.O. Resgate histórico da praça da Basílica de Bom Jesus de Matosinhos em Congonhas, Minas Gerais. Ornamental Horticulture, v.21, n.1, p.6376, 2015. https://doi.org/10.14295/rbho.v21i1.777

LARSON, L.R., JENNINGS, V., CLOUTIER, S.A. Public Parks and wellbeing in urban areas of the United States. PLoS One, v.11, n.4, e0153211. 2016.

LORENZI, H. Árvores Brasileiras: manual de identificação e cultivo de plantas arbóreas nativas do Brasil. vol.3. Nova Odessa: Instituto Plantarum, 2016. 384p.

LUZ, I.C.A.; PAIVA, P.D.O. Origin and situation of some squares of railway stations. Ornamental Horticulture, v.26, n.1,2020 p.69-76, 2020. https://doi.org/10.1590/2447536X.v26i1.2115

MARANHO, A.S.; PAULA, S.R.P. Diversidade em uma área verde urbana: avaliação qualitativa da arborização do campus da Universidade Federal do Acre, Brasil. Revista Agro@mbiente, v.8, n.3, p.404-415, 2014.

MARTINS, V.F.; CORREA, G.W. Avaliação da arborização da Praça Barão de Araras (Araras-SP). Revista Ciência, Tecnologia \& Ambiente, v.4, n.1, p.20-29, 2017.

MELO, E.F.R.Q.; CARASEK, M.; MELO, R.H.R.Q. Ecologia Urbana: vegetação arbórea de um município de pequeno porte. Revista Nacional de Gerenciamento de Cidades, v.7, n.48, p.56-69. 2019. 
MORO, M.F.; WESTERKAMP, C.; ARAÚJO, F.S. How much importance is given to native plants in cities' treescape? A case study in Fortaleza, Brazil. Urban Forestry \& Urban Greening, v.13, n.2, p.365-374. 2014.

MUNDIN, A.S.; PAIVA, P.D.O.; SOUZA, R.B.; BONIFÁCIO, F.L.; ALVES, S.F.N.S.C. Origin, historical and landscape evolution of the Expedicionários Square, São João Del Rei-MG. Ornamental Horticulture. v.23, n.4, p.460-467, 2017. https://doi.org/10.14295/oh.v23i4.1118

PFROMM NETTO, S. Dicionário de Piracicabanos. vol.1. São Paulo: Instituto Histórico e Geográfico de Piracicaba (IHGP), 2013. 584p.

REIS, H.; SCOLFORO, J.R.S.; OLIVEIRA, A.D.; FILHO, A.T.O.; MELLO, J.M. Floristic composition analysis, diversity and similarity of Atlantic forest fragments in Minas Gerais State-Brazil. Cerne, v.13, n.3, p.280-290, 2015.

ROBBA, F.; MACEDO, S.S. Praças Brasileiras. vol.2. São Paulo: Universidade de São Paulo Edusp, 2003. 311p.

RODRIGUES, R.R. A vegetação de Piracicaba e municípios de entorno. vol.10. Piracicaba: Instituto de Pesquisas e Estudos Florestais, Circular Técnica, 1999. 17p.

ROMANI, G.N.; GIMENES, R.; SILVA, M.T.; PIVETTA, K.F.L.; BATISTA, G.S. Análise quali-quantitativa da arborização na Praça XV de Novembro em Ribeirão PretoSP, Brasil. Revista Árvore, v.36, n.1, p.479-487, 2012.
SHANNON, C.E.; WIENER, W. The mathematical theory of communication. vol.3. Illinois: University of Illinois Press, 1949. 144p.

SHANAHAN, D.F., LIN, B.B., BUSH, R., GASTON, K.J., DEAN, J.H., BARBER, E., FULLER, R.A. Toward improved public health outcomes from urban nature. American Journal of Public Health, v.105, n.3, p.470477, 2015.

SANTAMOUR JÚNIOR, F.S. Trees for urban planting: diversity uniformity, and common sense. vol.7. Lisle: Lisle Proceedings, 1990. 391p.

SOUZA, R.C.; AGUIAR, R.T.; SILVA, L.T.A.; SILVA, L.A.; MARRA, R. C. Avaliação quali-quantitativa da arborização da praça Agostinho Nohama, Bairro Lauzane Paulista, São Paulo, SP. Revista da Sociedade Brasileira de Arborização Urbana, v.9, n.1, p.92-107. 2014.

TISCHER, J.C.; FORTE, A.R.; PEDROSO-DE-MORAES, C. Análise quali-quantitativa de indivíduos arbóreos das praças centrais do município de Leme, SP. Revista da Sociedade Brasileira de Arborização Urbana, v.9, n.3, p.49-64, 2014.

TORRES, M.C.T.M. Piracicaba no Século XIX. vol.1. Piracicaba: Editora Equilíbrio, 2009. 247p.

XIE, C. Tree diversity in urban parks of Dublin, Ireland. Fresenius Environmental Bulletin, v.27, n.12/A, p.86958708, 2018. 